\title{
Pyrethrum (Chrysanthemum cinerariifolium) Flowers' Drying Conditions for Optimum Extractable Pyrethrins Content
}

\author{
H. O. Otieno ${ }^{1}$, D. K. Kariuki ${ }^{1} \&$ J. M. Wanjohi ${ }^{1}$ \\ ${ }^{1}$ Department of Chemistry, School of Physical Sciences, University of Nairobi, Nairobi, Kenya \\ Correspondence: H. O. Otieno, Department of Chemistry, School of Physical Sciences, University of Nairobi, \\ Nairobi, Kenya. E-mail: hillotow@gmail.com
}

Received: March 13, 2020

Accepted: May 4, 2020 Online Published: May 13, 2020

doi:10.5539/jps.v9n2p11

URL: https://doi.org/10.5539/jps.v9n2p11

\begin{abstract}
Pyrethrum flowers of the genus Chrysanthemum cinerariifolium are grown in Kenya by small scale farmers for extraction of pyrethrins, a natural insecticide's active ingredient. Pyrethrins are classified in two groups, Pyrethrins I and II, and are degradable when exposed to air, moisture and high temperatures. The contents and ratio of Pyrethrins I:II determine the efficacy of the insecticide. Therefore, drying of the pyrethrum flowers should be optimized in order to attain maximum extractable pyrethrins content and optimum ratio. The aim of this research was to optimize the drying temperatures, time and moisture content of pyrethrum flowers. The flowers were harvested and dried at varying temperatures of $40,50,60$ and $70{ }^{\circ} \mathrm{C}$ to total dryness. Another set of flowers were harvested and dried in the oven at the same temperatures for a maximum period of $18 \mathrm{hrs}$. Moisture content was determined at each temperature, at intervals of one hour. The dried flowers were then ground into fine powder and extracted using Soxhlet extraction method with hexane. The extracts were refined and analyzed by Mercury reduction and High Performance Liquid Chromatographic methods. Pyrethrum flowers were found to achieve maximum moisture loss, at varying times and temperature with $70{ }^{\circ} \mathrm{C}$ recording the shortest time of 18 hrs. The yield of pyrethrins obtained on drying the flowers to constant weight at $40{ }^{\circ} \mathrm{C}$ was $0.90 \%$ while drying for $18 \mathrm{hrs}$ yielded $0.79 \%$. Extractable Pyrethrins II were found to reduce by $8.6 \%$ when the drying temperature was raised from 50 to $60^{\circ} \mathrm{C}$ and by $11.3 \%$ from 60 to $70{ }^{\circ} \mathrm{C}$. Extractable Pyrethrins I were found to reduce by $6 \%$ when the drying temperature was raised from 50 to $60{ }^{\circ} \mathrm{C}$ and by $5 \%$ from 60 to $70{ }^{\circ} \mathrm{C}$. The total pyrethrins obtained from the flowers dried at $50{ }^{\circ} \mathrm{C}$ were found to be $1.37 \%$ at $18 \mathrm{hrs}$ and $1.44 \%$ to constant weight drying. The pyrethrins I:II ratio was found to vary over the temperature range $40-70^{\circ} \mathrm{C}$. The optimum temperature and time for drying pyrethrum flowers was found to be $50^{\circ} \mathrm{C}$ for $21 \mathrm{hrs}$.
\end{abstract}

Keywords: Chrysanthemum cinerariifolium, pyrethrins I:II ratio, drying, temperature, time

\section{Introduction}

Pyrethrum is a plant genus classified as Chrysanthemum or Tanacetum and is commercially cultivated for its flowers that are used to produce natural insecticides. The natural insecticide extracted from the dried flowers of C. cinerariifolium or C. coccineumare referred to as pyrethrins. Chrysanthemum cinerariifolium is the genus grown in Kenya and has white flowers, with yellow center that sprout from the stiff stems. The stems have bluish-green leaves and can grow to about 46-100 cm tall (Elliott, 2007). The growing of pyrethrum flowers in Kenya is of great economic value as it is an income generating activity for small scale farmers and also earns the country foreign exchange through the export of pyrethrins. Processing the flowers to extract pyrethrins is a long process involving many actors, such as agronomists, farmers, chemical engineers, chemists and entomologists. Processing starts with picking of the mature flowers with horizontal petals. The flowers are then dried at optimum conditions to total dryness and then ground into fine particles before extraction. Finely ground flower powder is better suited for use as an insecticide but the coarsely ground have long shelf life and deteriorates less. The dried flowers are then transported to the processing factories for extraction of pyrethrins which are the active components and sold as oleoresin (Ang'endu, 1994).

Great interest was taken in the various methods used in drying the flowers and the thermal effect on the stability of the active components of the flowers. Small scale farmers always spread the flowers on polythene sheets in direct sunlight or in a shade for about two weeks. More advanced farmers always use solar driers or roasters to hasten the drying process due to the quantity of the produce. In Japan, the flowers are hung upside down to dry 
which increases pyrethrin concentration. In the recent past due to the technological developments, use of oven was adopted as a faster and more efficient method of drying the flowers. During this process, drying temperature and moisture content of the flowers are of great significance and should be monitored. Research shows that pyrethrins are thermally and photochemically unstable. Heat causes rearrangements of the pyrethrins structure to form iso-pyrethrins which are insecticidally inactive. There are high chances that the resonance conjugation of the unsaturated side chain with the cyclopropane ring encampasses the disappearance of the vital activated methylene next to the ring and so reduces biological activity in iso-pyrethrins results (Wang, 2017). Pyrethrins are classified in two groups, Pyrethrins I and II. Pyrethrins I is composed of pyrethrin 1, jasmolin 1 and cinerin 1 while Pyrethrins II is composed of pyrethrin 2, jasmolin 2 and cinerin 2. The structures of the pyrethrins are shown in Figure 1.

Pyrethrins "knockdown" and "kill" insects by delaying the closure of voltage gated sodium ion channels in the nerve cells. Insecticidal and insect repellant properties of these compounds have been known for millennia and chrysanthemum species have long been cultivated for this purpose. Pyrethrins I are responsible for the knockdown and pyrethrins II for killing the insects. The knowledge of the ratio of pyrethrins I to pyrethrins II is of great importance since it helps in determining the efficacy of the insecticide. The highest efficacy is achieved with a pyrethrins I: II ratio of 1:1 (Wagner, 2000).

Pyrethrins as an insecticide is always applied in places where animals and human are present and therefore their toxicity must be considered. Pyrethrum as a mixture of cinerin, pyrethrin and jasmolin can be inhaled by people in their workplaces, it can get into the eye or the skin or it can be swallowed. A legal limit for pyrethrum exposure to humans has been set as $5 \mathrm{mg} / \mathrm{m}^{3}$ over an 8 hours workday (Costa, 2015). Pyrethrum becomes dangerous to health at the levels of $5000 \mathrm{mg} / \mathrm{m}^{3}$. Symptoms as pruritus (itching), dermatitis, papules, erythema, rhinorrhea, sneezing and asthma can be experienced by people exposed to pyrethrum. Safety equipment should be put on by people using pyrethrum (Mader, 2012). Due to the increasing use of pyrethins in agricultural and consumer products, there is a need for improved analytical techniques both to assure product quality and to monitor the fate of pyrethrins in the environment. The degradation of pyrethrins in pyrethrum flowers with respect to the moisture content and drying rates is also of great importance. Pyrethrins degrade when exposed to the environment hence insects are unable to develop resistance to the insecticide. This partly explains the insecticide's continuous use and efficacy for more than a century. It does not pose threat to human beings and animals since it does not persist in the environment (Power et al, 2007).

Pyrethrins I<smiles>C=C/C=C\CC1=C(C)C(OC(=O)C2C(C=C(C)C)C2(C)C)CC1=O</smiles>

Pyrethrin I<smiles>C/C=C/CC1=C(C)C(OC(=O)C2C(C=C(C)C)C2(C)C)CC1=O</smiles>

Cinerin I



Jasmolin I<smiles>C=C/C=C\CC1=C(C)C(OC(=O)C2C(/C=C(\C)C(=O)OC)C2(C)C)CC1=O</smiles>

Pyrethrin II<smiles>C/C=C/CC1=C(C)C(OC(=O)C2C(CC(C)C(=O)OC)C2(C)C)CC1=O</smiles><smiles>CC/C=C\CC1=C(C)C(OC(=O)C2C(/C=C(\C)C(=O)OC)C2(C)C)CC1=O</smiles>

Jasmolin II

Figure 1. Structures of pyrethrins

Source: Casida, 1995 
Processing of pyrethrins begins with the picking and drying of pyrethrum flowers. Mature pyrethrum flowers that are ready for picking are those that have petals lying horizontally. Flowers are picked and stored in dry, well ventilated bags for transport to drying sites or rooms. Drying of the flowers is an essential post-harvest activity that determines the extractable pyrethrins content. Farmers dry the flowers in the open, on materials such as mats, polythene sheet spread on the ground for a minimum of 4 days depending on sunlight (Wang, 2017).

\section{Materials and Methods}

\section{Sampling}

Once the flowers had horizontal petals, they were taken to have matured. The flowers were hand- picked ensuring that no part of the flower stock is taken. The flowers were picked in aerated baskets to avoid accumulation of heat generated by the picked flowers that may have led to rotting. The fresh flowers were weighed and then taken to the oven for drying.

\section{Drying of pyrethrum flowers at regulated known temperatures}

The harvested flowers were put on trays and then the trays were put in the oven. The temperatures of the oven were regulated between $30-70{ }^{\circ} \mathrm{C}$ at intervals of $10{ }^{\circ} \mathrm{C}$ but at constant time of $18 \mathrm{hrs}$. The moisture contents of the dry flowers were then tested and the flowers were then taken for analysis.

\section{Grinding}

The dried flowers were kept in the room for two days at ambient temperature before grinding, using a pestle and mortar. After grinding, the powder was sieved using a BS 410 mesh and put in labeled brown paper bags awaiting extraction.

\section{Reagents}

Dinige's reagent, potassium iodate standard solution, iodine mono-chloride all prepared using AOAC method 936.05, n-hexane, sodium hydroxide, barium chloride and methanol.

\section{Extraction Procedures}

\section{Step 1 Extraction}

The dried flowers were then placed into an extraction thimble. Extraction at varying temperatures was done using soxhlet extraction for 10 hours using $1000 \mathrm{ml} \mathrm{n}$-hexane in a $2000 \mathrm{ml}$ Erlenmeyer conical flask containing a few anti-bumping chips. After extraction, the $n$-hexane was removed through a rotor vapour to reduce extracts volume to about $50 \mathrm{ml}$.

\section{Step 2 Dewaxing}

Normal Hexane was added to the sample extracts in a flask at a ratio of $3: 1 \mathrm{v} / \mathrm{v}$ solvent to sample. The extracts were then kept in the refrigerator at $2{ }^{\circ} \mathrm{C}$ for a period of $12 \mathrm{hrs}$ for dewaxing. After $12 \mathrm{hrs}$, the extracts were filtered through cotton wool into conical flasks. The extracts were then evaporated to dryness using a rotor vapour.

\section{Step 3 Saponification}

A volume of $20 \mathrm{ml}$ alcoholic $\mathrm{NaOH}$ was then added into extracts and refluxed for 1 hour for saponification of the fatty acids. The extracts were then transferred into $250 \mathrm{ml}$ beakers after saponification.

\section{Step 4 Evaporation}

Distilled water was added to the extracts to a volume of $200 \mathrm{ml}$ and evaporated on a hot plate up to a volume of $150 \mathrm{ml}$ to remove the alcohol. The solution was then cooled to room temperature using tap water.

\section{Step 5 Fatty acid removal}

After cooling the solutions, they were transferred into $250 \mathrm{ml}$ volumetric flasks and $1.0 \mathrm{~g}$ of filter-Celite was added to each solution. A volume of $10 \mathrm{ml}$ of $10 \% \mathrm{BaCl}_{2}$ was added to the extracts and topped up to the mark with distilled water. The mixtures were then shaken vigorously to ensure that the fatty acids were removed by the $\mathrm{BaCl}_{2}$. Yellowish-orange Barium fatty acid salt precipitate was then formed. $200 \mathrm{ml}$ of the extracts were then filtered into $250 \mathrm{ml}$ beakers and three drops of phenolphthalein indicator was added. The filtrates were then neutralized with excess $20 \%$ sulphuric acid to precipitate the remaining $\mathrm{BaCl}_{2}$. White precipitate of $\mathrm{BaSO}_{4}$ formed was then filtered off through whatmann filter paper no. 1 coated lightly with a suspension of filter-Celite on a Buchner funnel aspirator. The precipitates were then washed severally with distilled water. 
The filtrates obtained in step 5 above were then transferred into a $500 \mathrm{ml}$ separating funnel and extracted twice with two $50 \mathrm{ml}$ portions of petroleum ether. The petroleum ether layers were transferred into a $250 \mathrm{ml}$ separating funnel and washed twice with $5 \mathrm{ml}$ of distilled water to remove aqueous portions that were emptied into $250 \mathrm{ml}$ beakers. The Chrysanthemic acid is less polar than the pyrethric acid formed and therefore, the pyrethrins I are contained in the petroleum ether layer while the aqueous layer contain pyrethrins II. The main goal achieved in this step was the separation of the two acids subsequently used in quantifying the pyrethrins I and pyrethrins II. The aqueous layer was then evaporated to $50 \mathrm{ml}$ for 1 hour. The mixture was then cooled to room temperature using tap water.

\section{Analytical Methods}

\section{Titrimetric Method of Determination of Pyrethrins I}

The petroleum ether layers were extracted twice using $5 \mathrm{ml} 0.1 \mathrm{M} \mathrm{NaOH}$ solution. Chrysanthemic acid was mixed with $0.1 \mathrm{M} \mathrm{NaOH}$ and placed in $100 \mathrm{ml}$ beakers formed a basic extract, while the petroleum ether layers were discarded.

\section{Mercury Reduction}

A volume of $10 \mathrm{ml}$ of Dinige's reagent was added to the basic extract then kept in the dark for one hour in a water-bath at $25^{\circ} \mathrm{C}$. The colour of the solution changed gradually to purple-light blue-deep blue-green which is characteristic of Chrysanthemic acid on adding Dinige's reagent. The intensity of these colours depend on the concentration of the acid. The mixture was then removed from the dark and immediately $3 \mathrm{ml}$ of saturated $\mathrm{NaCl}$ solution was added followed by $20 \mathrm{ml}$ amyl alcohol. The saturated $\mathrm{NaCl}$ precipitates Mercurous Chloride $(\mathrm{HgCl})$. The precipitate was boiled, filtered and a further $10 \mathrm{ml}$ amyl alcohol added to precipitate remaining $\mathrm{HgCl}$. The white precipitate of $\mathrm{HgCl}$ was filtered and the filter paper washed twice with $10 \mathrm{ml}$ of distilled chloroform, so as to remove the alcohol. The beaker was washed with $50 \mathrm{ml}$ of $60 \% \mathrm{HC} 1$ aqueous solution and the piece of cotton wool into the $200 \mathrm{ml}$ conical flask-containing the filter paper and $\mathrm{HgCl}_{(\mathrm{s})}$. Further $20 \mathrm{ml}$ of $\mathrm{CHCl}_{3}$ was put into the $100 \mathrm{ml}$ beaker and added to the $200 \mathrm{ml}$ conical flask contents. Indicator iodine mono chloride (IC1) $1 \mathrm{ml}$, was added into the solution and titrated with $0.01 \mathrm{M} \mathrm{KIO}_{3}$ solution carried out. The titration was carried out with constant shaking until the pink colour in the chloroform phase just disappeared.

Calculations of Pyrethrins I concentration

The $\%(w / w)$ Pyrethrins I was calculated using equation 1,

$$
\% \text { Pyrethrins } \mathrm{I}=0.7125 \times \frac{V_{1}}{W_{1}}
$$

$\mathrm{V}_{1}$ - Titre volume (volume of $0.01 \mathrm{M} \mathrm{KIO}_{3}$ used) $(\mathrm{cm} 3)$

$\mathrm{W}_{1}$ - Weight of sample (g)

0.7125 - Stoichiometric factor for pyrethrins I

\section{Determination of Pyrethrins II}

After evaporating the aqueous layer containing Pyrethrins II in Step 6 above to about $50 \mathrm{ml}$ and cooling to $20^{\circ} \mathrm{C}$, the solution was transferred into a separating funnel containing a saturated solution of $\mathrm{NaCl}$. The sodium chloride solution supersaturates the aqueous layer and reduces the solubility of pyrethric acid in the aqueous layer. The aqueous layer was then extracted three times with diethyl ether and $10 \mathrm{ml}$ portions of saturated $\mathrm{NaCl}$ solution to remove traces of $\mathrm{HC} 1$. The diethyl ether layer was then filtered through a cotton plug and the filtrate evaporated to dryness before putting it in an oven at $100{ }^{\circ} \mathrm{C}$ for ten minutes. On removing the aliquot from the oven, a current of compressed air was blown into the flask to remove $\mathrm{HCl}$ fumes. The aliquot was then dissolved in $2 \mathrm{ml}$ of neutral alcohol and $20 \mathrm{ml}$ of water was added. The neutral alcohol and water were prepared by neutralizing both with dilute sodium hydroxide to $\mathrm{pH}$ 7. The aliquot was titrated against with $0.02 \mathrm{~N} \mathrm{NaOH}$ with phenolphthalein indicator.

\section{Calculation of Pyrethrins II concentration.}

$$
\text { The percentage }(\mathrm{w} / \mathrm{w}) \text { Pyrethrins } \mathrm{II}=0.4675 \times \frac{V_{2}}{W_{2}} \times \mathrm{TF}
$$

$\mathrm{V}_{2}=$ Volume of $0.02 \mathrm{~N} \mathrm{NaOH}\left(\mathrm{cm}^{3}\right)$

$\mathrm{W}_{2}=$ Weight of Sample extracted $(\mathrm{g})$

$\mathrm{TF}=$ Titration factor due to the hygroscopic alkali base $\mathrm{NaOH}$

$0.4675=$ Stoichiometric factor for Pyrethrins II 


\section{Ultra-High Performance Liquid Chromatography (UHPLC) Analysis Samples}

One gram sample of the grist was each extracted in triplicates using $n$-hexane in volumetric flasks. The extract was then left to settle for three hours before injection into the UHPLC instrument. This procedure was repeated the following day for reproducibility.

\section{Instrument}

A Varian Model 5000 liquid chromatograph equipped with a UV-100 detector, a flow cell $4.5 \mu 1$ and an integrator model 4400 was used.

\section{Operational conditions}

Detector settings - lambda max 230nm; Absorbance range $=0.5$ Auf

High pressure pump: multi-head reciprocating type capable of minimizing pulsation

Flow rate $-0.8 \mathrm{ml} / \mathrm{min}$

Integrator settings: chart speed $=1 \mathrm{~cm} / \mathrm{min}$

Attenuation $=8 ;$ Peak threshold $=6$

Pressure: 14-16 atmospheres

Syringe; $10 \mu 1$ Hamilton syringe

Solvents: Acetonitrile - HPLC grade, water: methanol (10:90).

Column: a Varian micropak CN-5 nitrile, $30 \mathrm{~cm} \times 4 \mathrm{~mm}$ id and ambient column temperature.

Aliquots of 20 microliters were injected into the pot to be analyzed which is connected to the column through the sample injection system. The compounds in the aliquot mixture exhibit different flow rates through the adsorbent material in the column resulting in separation and quantification. The stationary phase is made of silica adsorbent material while the mobile phase is the pressurized mixture of solvents, water, methanol and acetonitrile. At the end of each analysis, the data recorded in the computer was passed through a "smoothing" routine to remove random electronic noise and then saved as a digital spectrum. The system was then ready for the next analysis.

The peaks of interest were identified by comparing with those of known standards and where there was ambiguity internal standardization was carried out.

Analysis was carried out in triplicates and the average peak area worked out. All the analyses were done at a wavelength of $230 \mathrm{~nm}$.

Percentage pyrethrins content was calculated as follows:

The percentage of Pyrethrins $(\mathrm{w} / \mathrm{w})=\mathrm{H}_{\mathrm{s}} \times \frac{\boldsymbol{c}_{s t d}}{\boldsymbol{H}_{s t d}} \times \mathrm{C}_{\mathrm{s}} \times \%$ Purity of pyrethrin standard

Where $\mathrm{H}_{\mathrm{s}}=$ Average peak height of sample

$\mathrm{H}_{\text {std }}=$ Average peak height of pyrethrin standard

$\mathrm{C}_{\mathrm{s}}=$ Concentration of sample $(\mathrm{gm} / 1)$

$\mathrm{C}_{\mathrm{std}}=$ Concentration of pyrethrin standard

\section{Results and Discussion}

\section{Drying at different temperatures at a constant time}

The logarithm of moisture content lost at given temperatures was plotted against time. 


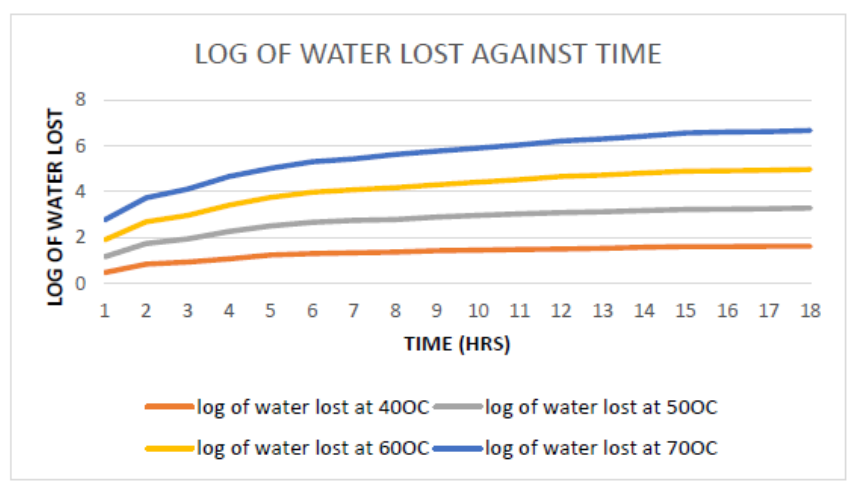

Figure 2. Graphical representation of the weight loss during drying

The graphs above show that much water is lost in the first one hour of drying across all the drying temperatures. After drying for about $12 \mathrm{hrs,} \mathrm{there} \mathrm{is} \mathrm{insignificant} \mathrm{change} \mathrm{in} \mathrm{moisture} \mathrm{content} \mathrm{loss.} \mathrm{This} \mathrm{shows} \mathrm{that} \mathrm{once} \mathrm{the}$ moisture content of the flowers is below $10 \%$, high quantity of pyrethrins is obtained. However, when the drying is done for a longer period at temperatures above $60{ }^{\circ} \mathrm{C}$, this leads to a negative change in the quantity of the pyrethrins due degradation.

\section{Drying to total dryness at different temperatures and time}

When the flowers were dried to total dryness at different temperatures, they dried at different times.

Table 1. Drying to total dryness at different temperatures and time

\begin{tabular}{llll}
\hline Temperature $\left({ }^{\mathbf{0}} \mathbf{C}\right)$ & Time (Hrs) & Weight Lost $(\%)$ & Log Weight Lost \\
\hline 40 & 26 & 71.2 & 1.85 \\
50 & 21 & 75.3 & 1.88 \\
60 & 19.5 & 75.8 & 1.88 \\
70 & 18 & 77.1 & 1.89 \\
\hline
\end{tabular}

Pyrethrum flowers were dried to total dryness at varying temperatures of $40,50,60$ and $70{ }^{\circ} \mathrm{C}$. The logarithm of loss of moisture content was found to marginally increase over the temperature range. The moisture content loss was stable at $50-60^{\circ} \mathrm{C}$ range.

Table 2. Percentage (\%) of Pyrethrins on drying at different temperatures for 18 hours

\begin{tabular}{lllll}
\hline Temperature $\left({ }^{\mathbf{0}} \mathbf{c}\right)$ & Pyrethrins I & Pyrethrins II & Total Pyrethrins & Ratio (PI:PII) \\
\hline 40 & 0.46 & 0.33 & 0.79 & $1: 0.72$ \\
50 & 0.79 & 0.58 & 1.37 & $1: 0.73$ \\
60 & 0.77 & 0.53 & 1.30 & $1: 0.69$ \\
70 & 0.73 & 0.47 & 1.20 & $1: 0.64$ \\
\hline
\end{tabular}

Total extractable pyrethrins content were found to vary with drying temperature. At $40{ }^{\circ} \mathrm{C}$, the extractable pyrethrins content was recorded as $0.79 \%$ and $1.37 \%$ at $50{ }^{\circ} \mathrm{C}$. However, the total extractable pyrethrins content as well as the Pyrethrins I : II ratio was found to reduce with increase in temperature beyond $50^{\circ} \mathrm{C}$.

Table 3. Percentage of Pyrethrins on drying to a constant weight

\begin{tabular}{|c|c|c|c|c|}
\hline Temperature $\left({ }^{\circ} \mathrm{c}\right)$ & Pyrethrins I & Pyrethrins II & Total Pyrethrins II & Ratio (PI:PII) \\
\hline 40 & 0.53 & 0.37 & 0.90 & $1: 0.70$ \\
\hline 50 & 0.83 & 0.61 & 1.44 & $1: 0.73$ \\
\hline 60 & 0.78 & 0.56 & 1.34 & $1: 0.72$ \\
\hline 70 & 0.74 & 0.49 & 1.23 & 1:0.66 \\
\hline
\end{tabular}

Total extractable pyrethrins content was found to vary with drying temperature, with a peak at $50{ }^{\circ} \mathrm{C}$ and lowest at $70{ }^{\circ} \mathrm{C}$. At $40{ }^{\circ} \mathrm{C}$, the pyrethrins content was found to be $0.90 \%$ and $1.44 \%$ at $50{ }^{\circ} \mathrm{C}$, implying that, there was loss of pyrethrins at low temperatures. Thus, there were more extractable pyrethrins I and II when flowers were dried at 50 than $40{ }^{\circ} \mathrm{C}$. However, beyond $50^{\circ} \mathrm{C}$, both extractable pyrethrins I and II were found to reduce, hence 
affecting the ratio and total pyrethrin content. Extractable pyrethrins II were found to reduce by $8.6 \%$ when the drying temperature was raised from 50 to $60{ }^{\circ} \mathrm{C}$ and by $11.3 \%$ from 60 to $70{ }^{\circ} \mathrm{C}$. Extractable pyrethrins I were found to reduce by $6 \%$ when the drying temperature was raised from 50 to $60{ }^{\circ} \mathrm{C}$ and by $5 \%$ from 60 to $70{ }^{\circ} \mathrm{C}$. Extractable pyrethrins II were found to reduce at a higher rate with increase in temperature beyond $50{ }^{\circ} \mathrm{C}$ compared to pyrethrins I, thereby affecting the ratio.

High Performance Liquid Chromatographic analyses was carried out on the pyrethrin extracts. The chromatograms attained are presented in Figures 3 and 4. Figure 4 show chromatograms for pyrethrins dried at $50{ }^{\circ} \mathrm{C}$ to total dryness.

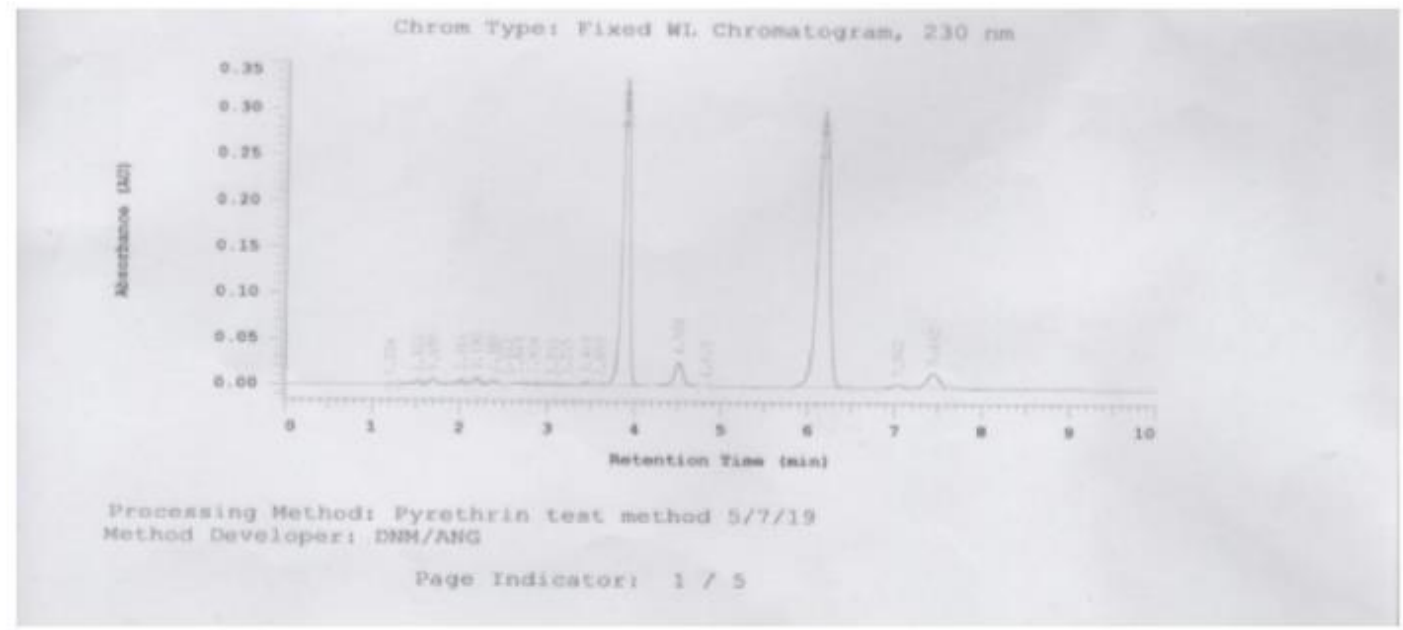

Figure 3. Chromatograms of the standard



Figure 4. Chromatograms for the sample dried at $50{ }^{\circ} \mathrm{C}$ to total dryness

Results obtained from flowers dried at $50^{\circ} \mathrm{C}$ to constant weight are presented in table 4 . 
Table 4. \% Pyrethrins obtained using HPLC

\begin{tabular}{lllll}
\hline Temperature $\left({ }^{\mathbf{0}}\right.$ ) & Pyrethrins I (\%) & Pyrethrins II (\%) & Total Pyrethrins (\%) & Ratio (PI:PII) \\
\hline 50 & 0.85 & 0.61 & 1.46 & $1: 072$ \\
\hline
\end{tabular}

\section{Conclusion}

Total extractable pyrethrins content from pyrethrum flowers was highest at $1.44 \%$ and pyrethrins I:II ratio of 1:0.73, when dried at $50{ }^{\circ} \mathrm{C}$ at a time of $21 \mathrm{hrs}$, thereby presenting the optimum drying temperature and time. The flowers were dried to a constant moisture content of less than $10 \%$. Drying flowers at a higher temperature of 70 ${ }^{\circ} \mathrm{C}$ resulted to lower yields of $1.20 \%$ and pyrethrins I:II ratio of $1: 0.64$ while at $40{ }^{\circ} \mathrm{C}$ resulted in $0.79 \%$ which is $0.65 \%$ lower compared to that of $50^{\circ} \mathrm{C}$.

\section{Acknowledgements}

The authors would like to appreciate the University of Nairobi for providing research facilities, pyrethrum growing sites that enabled the successful completion of this research work.

\section{References}

Aldridge, W. N. (1990).An Assessment of the Toxicological Properties of Pyrethroids and Their Neurotoxicity. Critical Reviews in Toxicology, 21(2), 89-104. https://doi.org/10.3109/10408449009089874

Ang'endu Charles. A (1994). Determination of the relationship between the pyrethrins and yellow pigmentation in pyrethrum flowers. Msc. Thesis University of Nairobi.

Anonym. (1987). Pepping up Pesticides Naturally. Organic Gardening, 34(3), 8.

Bai Chi Sun, B. E, (1994), Drying pyrethrum faculty of engineering. Msc thesis university of Tasmani, p. 32-60

Caldwell, B., Eric, S., Abby, S., Anthony, S., \& Christine, S. (2013). Resource Guide for Organic Insect and Disease Management. (n.d.): n. pag. Cornell University.

Casida, J. E., \& Quistad, G. B. (Eds). (1995). Pyrethrum Flowers' Production. Chemistry, Toxicology, and Uses. Oxford University Press, Oxford.

Casida, J. E., (Ed.) (1973). Pyrethrum, The Natural Insecticide. Academic Press, New York. Cox, C. (2002). Pyrethrins/Pyrethrum Insecticide

Costa, L. G. (2015). The neurotoxicity of organochlorine and pyrethroid pesticides. Handb. Clin. Neurol., 131, 135-148. https://doi.org/10.1016/B978-0-444-62627-1.00009-3

Czeslaw, S., \& Tadeusz, K. (1986). Drying: principles, applications and design.

Elliott, M. (2007). The pyrethrins and related compounds. II. infra-red spectra of the pyrethrins and of other constituents of pyrethrum extract. Journal of Applied Chemistry, 11(1), 19-23. https://doi.org/10.1002/jctb.5010110105

Gradiger, C. B., Evans, I. E., \& Carl, C. S. (1933). Pyrethrum investigations in Colorado. Colorado Agricultural College Experiment Station Bulletin 401. p. 19.

Grain, C. F., Vapor, P., Lyman, W. J., Reehl, W. F., \& Rosenblatt, D. H. (1982). Handbook of Chemical Property Estimation Methods: Environmental Behavior of Organic Compounds. McGraw-Hill, New York, p. 1-14.

Grieve, M. (1981). A modern herbal. Dover Publications, New York. Volume II, p. 902.

Head, S. W. (1966). The Quantitative Determination of Pyrethrins by Gas-Liquid Chromatography. Part 1: Detection by Electron Capture Pyrethrum. Post, 8(4), 3-7.

Henn, T., \& Weinzierl, R. (1989). Botanical insecticides and insecticidal soaps. University of Illinois Cooperative Extension Service, circular 1296, p. 2.

Ivera, S. B., Swedlund, B. D., King, G. J., Bell, R. N., Hussey, C. E., Shattuck-Eidens, D. M., \& Poulter, C. D. (2001). Chrysanthemyl diphosphate synthase: Isolation of the gene and characterization of the recombinant non-head-to-tail monoterpene synthase from Chrysanthemum cinerariaefolium. https://doi.org/10.1073/pnas.071543598

Mackay, D., Shiu, W. Y., \& Ma, K. C. (1992). Illustrated Handbook of PhysicalChemical Properties and Environmental Fate for Organic Chemicals. Polynuclear Aromatic Hydrocarbons, Polychlorinated Dioxins, and Dibenzofurans, Lewis Publishers, Chelsea, 2(3), 250-252. 
Mackay, D., Shiu, W. Y., \& Ma, K. C. (2000). Henry's law constant. In R. S. Boethling \& Mackay, D. (Eds.), Handbook of Property Estimation Methods for Chemicals: Environmental and Health Sciences (pp. 69), CRC Press, Boca Raton, FL. https://doi.org/10.1201/9781420026283.pt2

Mader, E., \& Nancy, L. A. (2012). Organic-Approved Pesticides. Organic-Approved Pesticides: The Xerces Society for Invertebrate Conservation.

Matsuo, N., Takagaki, T., Watanabe, K., \& Ohno, N. (1993). The First Practical Synthesis of (S)-Pyrethrolone, an Alcohol Moiety of Natural Pyrethrins I and II. Biosci. Biotechnol. Biochem., 57(4), 693-694. https://doi.org/10.1271/bbb.57.693

Njiru, S. (2006). Combination of Pyrethrins and Retenoids and its environmental implications as a strategy in integrated pest management. MSc. Thesis, University of Nairobi.

Occupational Health Services, Inc. (1987). Pyrethrum. Material Safety Data Sheet. New York: OHS.

Otieno, D. A., Jondiko, I. J., Me. Dowell, P. G., \& Kezdy, F. J. (1982). Quantitative Analysis of the Pyrethrins by HPLC. Journal of Chromatographic Science, 20(12), 566-570. https://doi.org/10.1093/chromsci/20.12.566

Otieno, D. A., Jondiko, I. J., Me. Dowell, P. G., \& Kezdy, F. J. (1983). Pyrethrum Post, 15(3), 71-75.

Power, L. E., \& Sudakin D. L. (2007). Pyrethrin and pyrethroid exposures in the United States: A longitudinal analysis of incidents reported to poison centers. Journal of Medical Toxicology, 3(3), 94-9. https://doi.org/10.1007/BF03160917

Raymond, K. M. (1994). Thesis, Quantitative and qualitative analysis of pyrethrins and pyrethrosin. MSc Thesis, University of Nairobi. p. 56-79.

Robert, L. M. (2002). "Insect Control" in Ullmann's Encyclopedia of Industrial Chemistry. Wiley-VCH, Weinheim.

Scoog, D., West, D., \& Holler, J. (1992). Fundamentals of Analytical Chemistry. Saunders College Publishing, Philadelphia.

Singleton, S. T., Lein, P. J., Farahat, F. M., Farahat, T., Bonner, M. R., Knaak, J. B., \& Olson, J. R. (2014) Characterization of $\alpha$-cypermethrin exposure in Egyptian agricultural workers. Int. J. Hyg. Environ. Health, 217, 538-545. https://doi.org/10.1016/j.ijheh.2013.10.003

Susan, B. R., Bradley, D. S., Gretchen, J. K., Russell, N. B., Charles, E. H., Jr., Donna, M. S-E., ...Dale, C. (2001). Poulter Chrysanthemyl diphosphate synthase: Isolation of the gene and characterization of the recombinant non-head-to-tail monoterpene synthase from Chrysanthemum cinerariaefolium. Proceedings of the National Academy of Sciences, 98, 4373-4378. https://doi.org/10.1073/pnas.071543598

Thomas, R. G. (1982). Volatilization from water. In W. J. Lyman, W. F. Reehl \& D. H. Rosenblatt (Eds.), Handbook of Chemical Property Estimation Methods: Environmental Behavior of Organic Compounds (pp. 1-15). McGraw-Hill, New York.

US Environmental Protection Agency Office of Pesticide Programs. (2009). Review of the Relationship between Pyrethrins, Pyrethroid Exposure and Asthma and Allergies

Wagner, S. (2000). Fatal Asthma in a Child After Use of an Animal Shampoo Containing Pyrethrin. Western Journal of Medicine. https://doi.org/10.1136/ewjm.173.2.86

Wainaina, J. M. G. (1995). Pyrethrum Flowers - Production in Africa. In J. E. Casida \& G. B. Quistad (Eds.), Pyrethrum Flowers. Oxford University Press.

Wang, Y., Lv, L., Yu, Y., Yang, G., Xu, Z., Wang, Q., \& Cai, L. (2017) Single and joint toxic effects of five selected pesticides on the early life stages of zebrafish (Deniorenio). Chemosphere, 170, 61-67. https://doi.org/10.1016/j.chemosphere.2016.12.025

Wanjala, N., Busiene, T. P., \& Perte, E.P. (2008). KARI information bronchure series.

\section{Copyrights}

Copyright for this article is retained by the author(s), with first publication rights granted to the journal.

This is an open-access article distributed under the terms and conditions of the Creative Commons Attribution license (http://creativecommons.org/licenses/by/4.0/). 